\title{
Non-Hospital Based Cell or Tissue Processing Facility
}

National Cancer Institute

\section{Source}

National Cancer Institute. Non-Hospital Based Cell or Tissue Processing Facility. NCI

Thesaurus. Code C133323.

A cell or tissue processing facility that is not located within a hospital. 